\title{
The use of lime to alleviate high pasture manganese in Central Otago
}

\author{
L. C. SMITH ${ }^{1}$, K. D. TRAINOR ${ }^{2}$ and W. D. CATTO ${ }^{3}$ \\ ${ }^{1}$ AgResearch, Woodlands Research Station, R.D. 1, Invercargill \\ ${ }^{2}$ AgResearch, P.O. Box 228, Alexandra \\ ${ }^{3}$ Ballance Agri-Nutrients, PB 12503, Mount Maunganui
}

chris.smith@agresearch.co.nz

\begin{abstract}
Rates of lime $(0,1.25,2.5,5.0,7.5$ and $10 \mathrm{t} / \mathrm{ha})$ were applied to two sites (Wyuna and Routeburn Stations) near Glenorchy in Central Otago. At both these sites initial herbage manganese (Mn) concentrations (780 and $471 \mathrm{mg} / \mathrm{kg}$ dry matter (DM) respectively) were above the level $(400 \mathrm{mg} / \mathrm{kg} \mathrm{DM})$ that has been shown to reduce lamb growth rates. Total pasture production for the three years averaged $3600 \mathrm{~kg} \mathrm{DM} / \mathrm{ha} / \mathrm{yr}$ at Wyuna and 8400 $\mathrm{kg} \mathrm{DM} / \mathrm{ha} / \mathrm{yr}$ at Routeburn. The application of lime to the predominately browntop (Wyuna $=72 \%$, Routeburn $=46 \%$ ) pastures in this study, did not result in significant pasture production increases in the first 2 years but in Year 3 there was a significant production increase due to lime at Wyuna $(\mathrm{P}<0.05)$. Significant increases in soil $\mathrm{pH}$ and calcium and decreases in soil Mn occurred with the application of lime. The lime application also resulted in significantly lower herbage $\mathrm{Mn}$ concentrations. One year following lime application at rates of only $2.5 \mathrm{t} / \mathrm{ha}$, herbage Mn concentrations were lowered to below the $400 \mathrm{mg} / \mathrm{kg}$ DM animal health threshold at both sites. A relationship between sward dead material content (x) and herbage Mn concentration (y) was established which had different slopes at the two sites (Routeburn $\mathrm{y}=8.34 \mathrm{x}$ $+577 ; \mathrm{r}^{2}=0.683, \mathrm{P}<0.001$ : Wyuna $\mathrm{y}=6.8 \mathrm{x}+633 ; \mathrm{r}^{2}$ $=0.640, \mathrm{P}<0.01)$. This relationship, the slope of which decreased as lime application rates increased, has implications in the interpretation and likely implementation of the results. It would thus appear that improved grazing management which limits the dead material content in the sward would lessen the amount of lime required to lower herbage $\mathrm{Mn}$ to below the animal health threshold.
\end{abstract}

Keywords: browntop, dead material, lime application, manganese

\section{Introduction}

Manganese (Mn) levels in New Zealand pastures are generally not considered to be high enough to adversely influence pasture production (Smith \& Edmeades 1983). However increased herbage Mn levels may affect animal performance since Grace (1973) found that sheep fed pasture with Mn levels in excess of $400 \mathrm{mg} / \mathrm{kg}$ dry matter (DM) had their daily weight gains decreased by about $40 \%$. While levels as high as this are not common in
New Zealand, they can be found in parts of Central Otago (Catto pers. comm.). As the pasture concentration of Mn fluctuates during the year, with concentrations reported as being highest in the late summer period (JanuaryMarch, Metson et al. 1979), it is likely that the growth rates of freshly weaned lambs at this time would be the most affected (Grace 1983).

On those $2 \%$ of farms where pasture $\mathrm{Mn}$ is above the $400 \mathrm{mg} / \mathrm{kg}$ DM threshold (Smith \& Edmeades 1983) the most effective means of lowering pasture $\mathrm{Mn}$ concentration appears to be the application of lime. Edmeades et al (1983) found that on Allophanic soils, $7.25 \mathrm{t}$ lime/ha decreased $\mathrm{Mn}$ concentrations in both ryegrass and white clover. The decrease in Mn levels was only of the order of $50 \mathrm{mg} / \mathrm{kg} \mathrm{DM}$ and was apparent 3 months after the lime application. In contrast Old et al. (2000) found that $2 t /$ ha of lime significantly lowered herbage Mn concentrations on a Brown soil, while Wheeler (1998) found significant Mn decreases with 5t lime /ha on a Pallic soil. Wheeler (1998) also found that the Mn concentrations decreased by a greater amount in grass than in clover, and that there did not appear to be any seasonal differences.

This paper reports on two trials which were laid down in November 2001, in the Glenorchy region of Central Otago to study the effects of lime application on herbage Mn concentrations.

\section{Methods}

\section{Sites and experimental design}

Two sites were selected in the Glenorchy region at the head of Lake Wakatipu. One of the sites was on Wyuna Station at $650 \mathrm{~m}$ above mean sea level, while the other site was on Routeburn Station at $350 \mathrm{~m}$ above mean sea level. The soil at Wyuna was a Queenstown Brown soil with a $\mathrm{pH}$ of 4.7, Olsen phosphorus (P) of $10 \mu \mathrm{g} / \mathrm{ml}$, sulphate-sulphur (S) of $8 \mu \mathrm{g} / \mathrm{g}, \mathrm{CaCl}_{2}$ extracted soil aluminium (Al) of $12.2 \mu \mathrm{g} / \mathrm{g}$ and EDTA- extracted soil $\mathrm{Mn}$ of $96 \mu \mathrm{g} / \mathrm{g}$. At Routeburn the soil was a Matukituki Recent soil with a pH of 5.0, Olsen P of $27 \mu \mathrm{g} / \mathrm{ml}$, sulphate-S of $4 \mu \mathrm{g} / \mathrm{g}, \mathrm{Al}$ of $9.0 \mu \mathrm{g} / \mathrm{g}$ and $\mathrm{Mn}$ of $143 \mu \mathrm{g} / \mathrm{g}$. The pasture at Wyuna was predominantly browntop and sweet vernal, and had a history of little to no fertiliser application, while the Routeburn site was on a 20 year old run-out pasture with a history of infrequent fertiliser 
applications. The design of the trials was 6 rates of lime randomised within 4 replicates, giving 24 plots per site. Plot size was $2 \mathrm{~m}$ x $2 \mathrm{~m}$. Lime rates of $0,1.25,2.5,5,7.5$ and $10 \mathrm{t} / \mathrm{ha}$ lime, were applied to the plots on 24 November 2001. The trials were then fenced to exclude stock, including rabbits. Initially the trials were designed to investigate the effect of lime alone as if applied to the pasture instead of other fertiliser. Following the first two years, a decision was made to apply other fertiliser, to see if the effects of the different $\mathrm{pH}$ levels on $\mathrm{Mn}$ changed as fertility improved. Hence in August 2003, sulphur super was applied to 2 replicates at each site at a rate of $50 \mathrm{~kg} \mathrm{P} / \mathrm{ha}$, with the other 2 replicates receiving nitrogen (N) (as sulphate of ammonia) at a rate of $30 \mathrm{~kg} / \mathrm{ha} /$ month. Hence the results presented for the third year of the study are the main effect of lime only. Basal potassium (K) was applied at a rate of $50 \mathrm{~kg} / \mathrm{ha}$ as potassium chloride every 3 months.

\section{Sample collection and measurements}

At approximately monthly intervals during the season August - June, pasture production was measured by plate meter calibrated with 6 quadrat cuts at each measurement, and herbage collected for chemical analysis. Following the production measurement the herbage was trimmed and the clippings removed. Where there had been insufficient re-growth to measure this was recorded, though a sample was still collected for chemical analysis. The herbage samples collected (green material + dead material) were dried at $60^{\circ} \mathrm{C}$, then analysed for $\mathrm{Mn}$ $\left(\mathrm{HNO}_{3} / \mathrm{HClO}_{4}\right.$ digestion; ICP-OES determination, Boumans 1980). The February sample was also analysed for calcium $(\mathrm{Ca})$, magnesium $(\mathrm{Mg})$, sodium $(\mathrm{Na}), \mathrm{K}$ and iron in conjunction with the regular Mn analysis. Also in February a second herbage sample was taken and separated for species (ryegrass, browntop, Yorkshire fog, sweet vernal, Poa pratensis, crested dogstail, white clover, weeds and dead material) analysis, and from May 2002 onwards, a sample was separated into green material/dead material. Further samples were taken from a newly sown pasture adjacent to the Routeburn site from May 2002 so as to obtain some further data on the effect of newer species on the herbage Mn concentrations.

In November 2001 the sites were soil sampled (0$75 \mathrm{~mm}$ ) on a block basis, while plot samples were collected on 15 August 2002, 29 June 2003 and 8 May 2004 and analysed for the standard quicktest $\mathrm{K}, \mathrm{Mg}, \mathrm{Ca}$ and $\mathrm{Al}(\mathrm{CaCl}$ extraction, McLean 1965) and $\mathrm{Mn}(0.02 \mathrm{M}$ EDTA extraction, AA determination; Forbes 1976).

\section{Results and discussion}

While the Routeburn site produced considerable more pasture than the Wyuna site in the three years of measurement (Table 1), the only significant production response to the lime application occurred at Wyuna in Year $3(\mathrm{P}<0.05)$. The lack of response to lime as measured in the first two years of this study is not unknown (Smith \& Sinclair 1998; Old et al. 2000), despite the significant soil $\mathrm{pH}$ increases measured. It is possible that the lack of initial pasture response in this study is a result of a combination of high soil Al, low soil fertility and poor pasture species. This is supported by the work of Edmeades et al. (1991), who found that high Al affected pasture growth to a greater extent than low $\mathrm{pH}$. In contrast Old et al. (2000) suggested that increased amounts of ryegrass and white clover grew where lime had been applied, thus resulting in increased production 18 months after lime application. In this study the predominant species at both sites averaged over treatments in January 2002 was browntop (Wyuna $=72 \%$, Routeburn $=46 \%$ ), while at Routeburn there was also ryegrass $(7 \%)$, Yorkshire fog $(11 \%)$, sweet vernal $(11 \%)$ and white clover (9\%) present. By January 2004, with the increased fertility, the species had changed to be still mainly browntop $($ Wyuna $=41 \%$, Routeburn $=22 \%)$, but with ryegrass $($ Routeburn $=11 \%)$, sweet vernal $($ Wyuna $=$ $18 \%$, Routeburn $=19 \%)$, Yorkshire fog $($ Wyuna $=15 \%$, Routeburn $=16 \%)$ and white clover $($ Wyuna $=20 \%$,

Table 1 Pasture production (kg DM/ha) from the Wyuna and Routeburn sites for the period November 2001 to May 2004.

\begin{tabular}{|c|c|c|c|c|c|c|c|c|}
\hline \multirow[b]{2}{*}{ Lime (t/ha) } & \multicolumn{4}{|c|}{ Wyuna } & \multicolumn{4}{|c|}{ - Routeburn } \\
\hline & $2001 / 2002$ & $2002 / 2003$ & $2003 / 2004$ & Total & $2001 / 2002$ & $2002 / 2003$ & $2003 / 2004$ & Total \\
\hline 0 & 1416 & 2468 & 4380 & 8265 & 6545 & 9003 & 9295 & 24844 \\
\hline 1.25 & 1336 & 3002 & 7021 & 11359 & 5608 & 8456 & 9919 & 23982 \\
\hline 2.5 & 1341 & 2961 & 6504 & 10806 & 5597 & 8690 & 11128 & 25416 \\
\hline 5.0 & 1444 & 3284 & 6788 & 11516 & 6073 & 8828 & 10094 & 24994 \\
\hline 7.5 & 1482 & 3329 & 7269 & 12079 & 5463 & 9357 & 10319 & 25139 \\
\hline 10 & 1406 & 3150 & $\begin{array}{c}6494 \\
*\end{array}$ & 11050 & 6339 & 9648 & 10329 & 26316 \\
\hline $\operatorname{LSD}_{(P<0.05)}$ & 548 & 973 & 1624 & 2679 & 1014 & 1594 & 1163 & 2553 \\
\hline
\end{tabular}


Table 2 Mean soil pH, QT Ca, Mn $(\mu \mathrm{g} / \mathrm{g})$ and $\mathrm{Al}(\mu \mathrm{g} / \mathrm{g})$ levels for the Wyuna and Routeburn sites and new pasture $(n=4)$.

\begin{tabular}{|c|c|c|c|c|c|c|c|c|c|c|}
\hline \multirow[b]{2}{*}{$\begin{array}{l}\text { Treatment } \\
\text { (t lime/ha) }\end{array}$} & \multicolumn{3}{|c|}{ __ July 2002} & \multicolumn{3}{|c|}{ __ July 2003} & \multicolumn{4}{|c|}{ May 2004} \\
\hline & $\mathrm{pH}$ & $\mathrm{Ca}$ & $\mathrm{Mn}$ & $\mathrm{pH}$ & $\mathrm{Ca}$ & $\mathrm{Mn}$ & $\mathrm{pH}$ & $\mathrm{Ca}$ & $\mathrm{Mn}$ & Al \\
\hline \multicolumn{11}{|l|}{ Wyuna } \\
\hline 0 & 4.8 & 5.3 & 90 & 4.7 & 5 & 102 & 4.7 & 5.8 & 80 & 13.8 \\
\hline 1.25 & 5.1 & 6.0 & 139 & 5.1 & 7 & 164 & 5.1 & 7.1 & 104 & 7.1 \\
\hline 2.5 & 5.0 & 5.5 & 97 & 5.1 & 7 & 109 & 5.1 & 6.8 & 78 & 6.1 \\
\hline 5.0 & 5.3 & 5.3 & 78 & 5.5 & 7 & 67 & 5.6 & 8.9 & 71 & 2.5 \\
\hline 7.5 & 5.4 & 5.8 & 71 & 5.8 & 9 & 69 & 5.6 & 11.4 & 47 & 4.6 \\
\hline 10 & 5.5 & 6.3 & 77 & 5.9 & 10 & 65 & 5.9 & 11.5 & 47 & 1.4 \\
\hline$* *$ & & $*$ & $* * *$ & $* *$ & *** & *** & $* *$ & $* *$ & $* * *$ & \\
\hline $\operatorname{LSD}_{(\mathrm{P}<0.05)}$ & 0.3 & 1.2 & 42 & 0.3 & 2 & 26 & 0.4 & 1.1 & 27 & 4.2 \\
\hline \multicolumn{11}{|l|}{ Routeburn } \\
\hline 0 & 5.1 & 4.5 & 163 & 5.0 & 5 & 151 & 5.1 & 4.0 & 139 & 9.6 \\
\hline 1.25 & 5.5 & 5.8 & 135 & 5.4 & 7 & 124 & 5.3 & 6.8 & 115 & 4.5 \\
\hline 2.5 & 5.7 & 7.0 & 141 & 5.6 & 8 & 141 & 5.6 & 8.3 & 114 & 3.3 \\
\hline 5.0 & 6.1 & 9.3 & 111 & 5.9 & 11 & 98 & 6.2 & 12.3 & 75 & 1.9 \\
\hline 7.5 & 6.3 & 10.0 & 81 & 6.3 & 12 & 58 & 6.7 & 14.5 & 44 & 0.6 \\
\hline 10 & 6.3 & 9.3 & 64 & 6.4 & 12 & 58 & 6.8 & 15.3 & 32 & 1.5 \\
\hline & $* \star \star$ & $* \star * *$ & *** & $* \star \star *$ & *** & 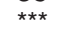 & 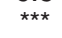 & $* \star \star *$ & *** & $t$ \\
\hline $\operatorname{LSD}_{(P<0.05)}$ & 0.2 & 1.8 & 40 & 0.1 & 2 & 20 & 0.2 & 1.7 & 26 & 6.0 \\
\hline $\begin{array}{c}\text { New } \\
\text { pasture }\end{array}$ & 5.4 & 8.0 & 96 & 5.4 & 8.0 & 96 & 5.1 & 4.0 & 120 & 15.9 \\
\hline
\end{tabular}

$\dagger P<0.10 ;{ }^{*} P<0.05 ;{ }^{* *} P<0.01 ;{ }^{* * *} P<0.001$.

Routeburn $=15 \%$ ). This change in pasture species was caused by the application of S super or N, as there were only small changes in clover content caused by the lime treatments (data not shown). The greater species change at Wyuna from the more Al-tolerant browntop to less Altolerant sweet vernal, Yorkshire fog and white clover (Wheeler et al. 1992), is likely to be partly responsible for the significant $(\mathrm{P}<0.05)$ pasture responses to the lime application at that site in Year 3. This raises the question of whether lime responses would have been apparent earlier if $\mathrm{P}$ and $\mathrm{S}$ fertiliser was applied from Year 1. It is possible that the application of $\mathrm{N}$ in Year 3 aided the lime response at Wyuna, as previous workers have found that lime responses on similar soils, though at higher altitudes were only apparent where $\mathrm{N}$ had been applied (McIntosh $\&$ Wales 1989). The same workers did not measure any lime response where $\mathrm{P}$ and $\mathrm{S}$ alone was applied.

There were significant $(\mathrm{P}<0.01)$ increases in soil $\mathrm{pH}$ and $\mathrm{Ca}$ and decreases in soil $\mathrm{Mn}$ with lime application (Table 2). At Wyuna the reduction in soil Mn levels was more variable than at the Routeburn site, with the $1.25 \mathrm{t}$ lime/ha rate having significantly higher Mn levels than all other treatments, including the control. This variability is mainly due to two of the control plots having lower than expected soil Mn levels initially. At both sites the application of $5 \mathrm{t}$ lime/ha significantly reduced the soil Mn levels below that of the control plots at the July 2003 sampling.

Despite the seasonal fluctuation in Mn status (Figure
1) which was slightly different to that previously reported (Metson et al. 1979; Edmeades et al. 1983) the application of lime was sufficient to lower the pasture $\mathrm{Mn}$ concentrations. There was a steady improvement apparent at Routeburn, and the wider variation in changes apparent at Wyuna. It would appear that by the end of the second year there is no benefit from lime rates greater than $5 \mathrm{t} / \mathrm{ha}$ and that even $1.25 \mathrm{t}$ lime /ha has lowered herbage Mn to satisfactory levels $(<400 \mathrm{mg} / \mathrm{kg}$ DM - Grace 1973) during the growing season, particularly at the Routeburn site. This result (Figure 1) was not unexpected as previous workers (Edmeades et al. 1983; Old et al. 2000; Wheeler 1998) had suggested that lime would lower herbage Mn concentration. However the drop in herbage $\mathrm{Mn}$ concentration we measured was consistently greater than that reported by Edmeades et al. (1983), and occurred at a lower application rate of lime ( $2.5 \mathrm{t} / \mathrm{ha}$ vs $7.5 \mathrm{t} / \mathrm{ha})$. Our results are similar to those of Old et al. (2000), where 18 months after application, a rate of $2 \mathrm{t} / \mathrm{ha}$ lime had lowered herbage Mn concentrations to below the $400 \mathrm{mg} / \mathrm{kg}$ DM threshold (Grace 1973).

The reason for the different seasonal behaviour of the two sites, as well as differing responses to lime in terms of herbage Mn concentration is at present unclear. Old et al. (2000) suggested that lower Mn concentrations were associated with more ryegrass and white clover in the lime treated swards. However we did not measure increases in ryegrass or clover with the lime application. In fact the opposite occurred at one site (Routeburn, data 
Figure 1 Changes in herbage Mn concentrations with time and lime applications (- Control, $1.25 \mathrm{t} / \mathrm{ha}, \bigcirc 2.5$

$\mathrm{t} / \mathrm{ha}, \boldsymbol{\nabla} 5 \mathrm{t} / \mathrm{ha}, \nabla 7.5 \mathrm{t} / \mathrm{ha}, \boldsymbol{\square} 10 \mathrm{t} / \mathrm{ha}$ ) for Wyuna and Routeburn trial sites. Bars are LSDP<0.05.
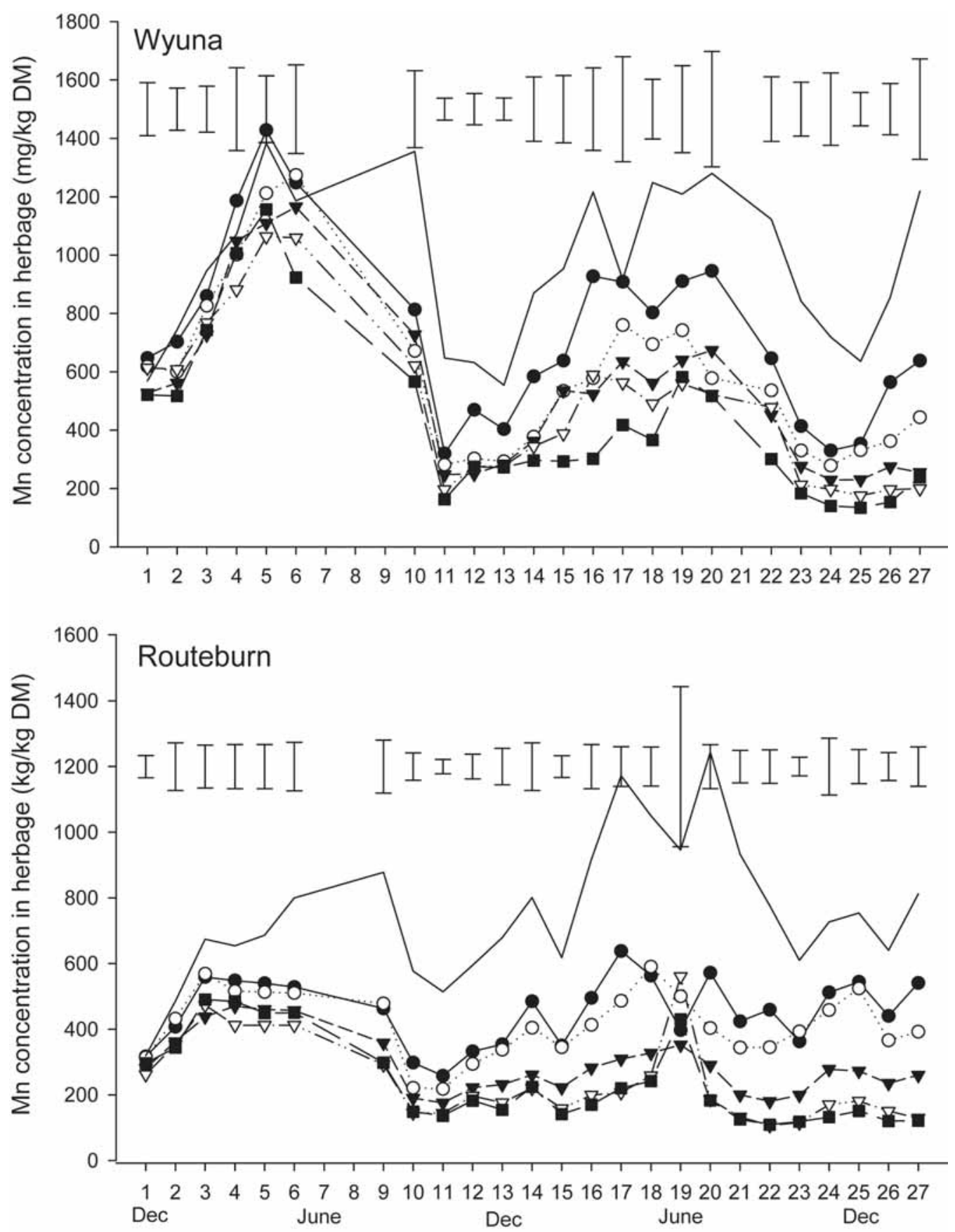

Months since lime applied

not presented). Despite this the difference between the two sites is probably due to the pasture species difference.

The seasonality of the herbage Mn concentrations is less clear. At both sites in this study the herbage Mn concentrations were at their lowest in late spring and their highest in the May-August period (Figure 1). The relationship between herbage Mn concentration of the control plots and the \% dead material on those plots is 
Figure 2 Relationship between herbage Mn concentration and dead matter content of pasture in control plots at the Wyuna and Routeburn trial sites. ( $\mathbf{\square}$, solid line Wyuna trial; $\nabla$, dotted line Routeburn trial; dashed line Routeburn new pasture).

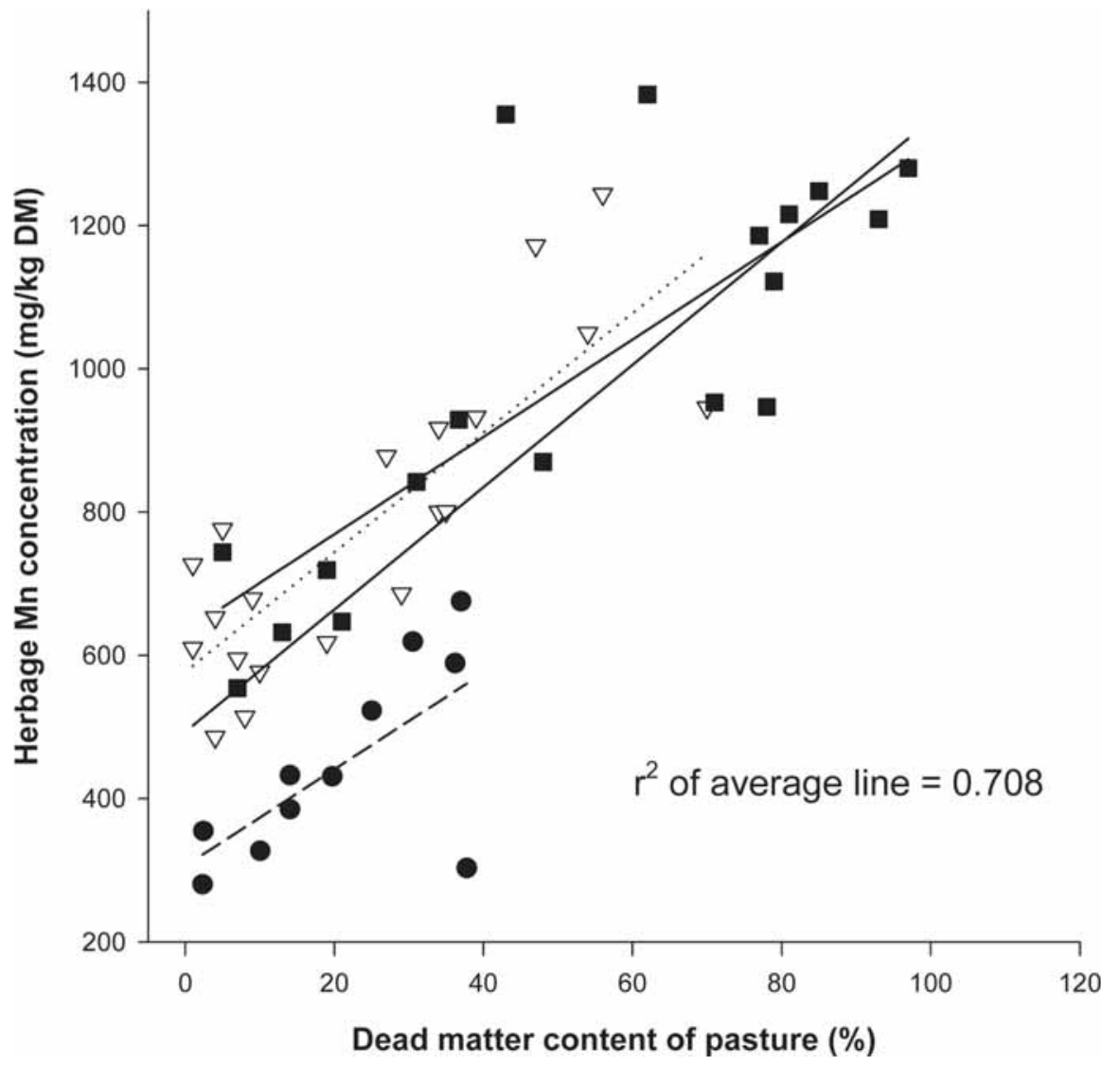

one possible explanation. This relationship, shown in Figure 2 for the control plots, was slightly different for each of the 3 sites measured (Routeburn trial $\mathrm{y}=8.34 \mathrm{x}+$ $577, \mathrm{r}^{2}=0.683, \mathrm{P}<0.001 ;$ Wyuna trial $\mathrm{y}=6.8 \mathrm{x}+633, \mathrm{r}^{2}$ $=0.451, \mathrm{P}<0.001$; Routeburn new pasture $\mathrm{y}=6.72 \mathrm{x}+$ $\left.307.4, \mathrm{r}^{2}=0.442, \mathrm{P}<0.05\right)$. The reason for the new pasture having the poorest relationship is due mainly to one sample point. This result was from the November 2002 sampling, after a particularly wet spring. However it must be noted that despite this the new pasture Mn concentrations were consistently lower than the older pasture at Routeburn (Figure 2), which is perhaps a reflection of the higher $\mathrm{pH}$ and lower soil $\mathrm{Mn}$ in this paddock (Table 2). Where lime had been applied (Wyuna and Routeburn) the relationships between the herbage Mn concentration and \% dead material were similar (Figure 3 ), with the lines being roughly parallel and moving down the Mn concentration axis with increasing lime inputs. It must be noted however that these relationships tended to weaken as the lime rate increased $\left(1.25 \mathrm{t} / \mathrm{ha} \mathrm{y}=6.68 \mathrm{x}+344, \mathrm{r}^{2}=0.541 ; 2.5 \mathrm{t} / \mathrm{ha} \mathrm{y}=5.1 \mathrm{x}+308\right.$ $\left.r^{2}=0.447 ; 5 t / h a y=5.66 x+207, r^{2}=0.457\right)$. The reason for this relationship is not fully understood, but other workers have noted that some nutrient concentrations can increase as the plant tissue ages and dies (Whitehead 1973; Williams et al. 1977).

The relationship between the pasture Mn and dead matter content (Figures 2 and 3 ) has implications in both the interpretation of the seasonal changes of Mn content and practical application of the results. The seasonal changes with higher pasture Mn concentrations in the winter months can be explained by this relationship as there was a significant increase in dead material over these months from less than $15 \%$ dead material in latespring/early-summer to in excess of $40 \%$ dead material in late-winter. Indeed Wheeler (1998) found that in a pasture with minimal dead material present there was no consistent seasonal change in herbage Mn concentrations.

Any management changes that have the ability to limit the amount of lime required is useful in hill country as the cost benefit of applying lime is aerially minimal (Floate et al. 1985). The results presented here suggest 
Figure 3 Relationship between herbage Mn concentration and dead matter content of pasture at varying rates of lime (- Control, $-1.25 \mathrm{t} / \mathrm{ha},-2.5 \mathrm{t} / \mathrm{ha}$, - $5 \mathrm{t} / \mathrm{ha}$ ) for the Wyuna and Routeburn trial sites. Horizontal line is the critical value for animal production.

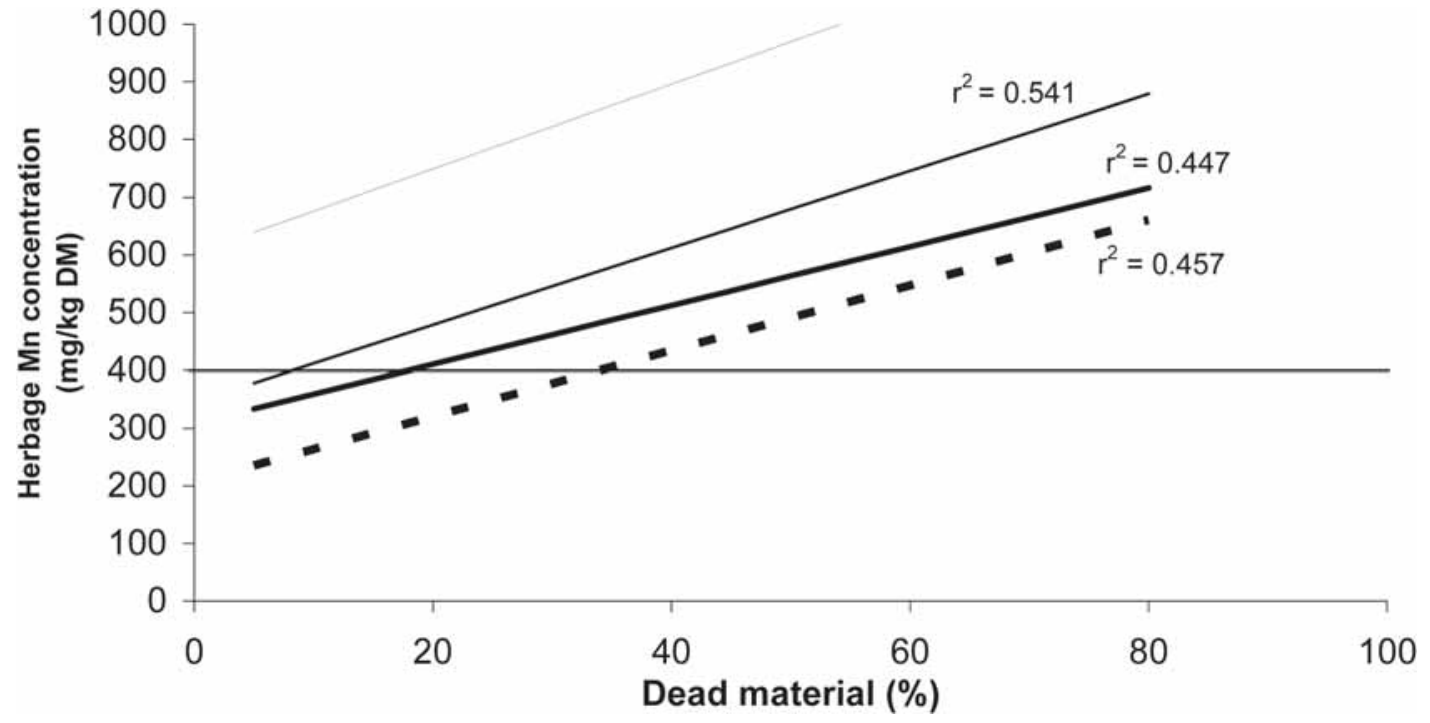

that changes in subdivision and management to improve utilisation, thus limiting the amount of dead material in the sward may be as effective in some situations as applying increased rates of lime. For example lowering the average content of dead material from $30 \%$ to $20 \%$ (Figure 3) would appear to halve the lime requirement to achieve the same herbage Mn concentration. Some lime is needed as these management changes are not enough on their own to alleviate the high Mn concentrations found in this study (Figure 3). However as the period of maximum herbage Mn concentration (late-winter, Figure 1) also coincides with the period of lowest pasture growth, totally removing the dead material out of the sward may prove impractical without the use of conserved feed alternatives.

\section{Conclusion}

The application of lime, in this study, while not initially resulting in pasture production increases, did significantly lower herbage $\mathrm{Mn}$ concentrations. One year following lime application at rates as low as $2.5 \mathrm{t} / \mathrm{ha}$, herbage $\mathrm{Mn}$ concentrations were lowered to below $400 \mathrm{mg} / \mathrm{kg} \mathrm{DM}$, at which level Mn intakes were unlikely to effect the growth rate of lambs. It would also appear that improved grazing management which limits the dead material content in the sward would lessen the amount of lime required to lower herbage $\mathrm{Mn}$ to these levels.

\section{ACKNOWLEDGMENTS}

The authors wish to acknowledge the assistance of the owners and managers of Routeburn Station and Wyuna
Station for allowing access to their properties. We also wish to thank Beth Henderson, Cristel Howden and Sue Smith for technical assistance. This research was funded by Ballance Agri-Nutrients.

\section{REFERENCES}

Boumans, P. 1980. Line Coincidence for ICPAES Spectroscopy, (Volumes 1 and 2). Pergamon Press, Oxford, England.

Edmeades, D. C.; Smart, C. E.; Wheeler, D. M.; Rys, G. 1983. Effects of lime on the chemical composition of ryegrass and white clover grown on a yellow-brown loam. New Zealand Journal of Agricultural Research 26: 473-481.

Edmeades, D. C.; Blamey, F. P. C.; Asher, C. J.; Edwards, D. G. 1991. Effects of $\mathrm{pH}$ and aluminium on the growth of temperate pasture species. I. Temperate grasses and legumes supplied with inorganic nitrogen. Australian Journal of Agricultural Research 42: 559569.

Floate, M. J. S.; McIntosh, P. D; Risk, W. H.; Enright P. D.; Smith, L. C. 1985. Effects of fertilisers and environment on lotus production on high country acid soils in Otago. Proceedings of the New Zealand Grassland Association 46: 111-118.

Forbes, E.A. 1976. Cobalt, copper, and zinc in yellowbrown pumice soils under grazed, permanent pasture. New Zealand Journal of Agricultural Research 19: 153-164.

Grace, N. D. 1973. Effect of high dietary Mn levels on the growth rate and the level of mineral elements in the 
plasma and soft tissues of sheep. New Zealand Journal of Agricultural Research 16: 177-180.

Grace, N. D. 1983. Manganese. pp. 80-83. In: The Mineral Nutrition of Grazing Ruminants. Ed. Grace, N.D. New Zealand Society of Animal Production Occasional publication No. 9.

McIntosh, P. D.; Wales, J F. 1989. What is the maximum production of Otago hill country above 700 metres altitude. Proceedings of the New Zealand Grassland Association 50: 243-247.

McLean, E. O. 1965: Aluminium. pp. 987-990. In: Ed. Blake, C. A. Methods of Soil Analysis, Part 2, Chemical and Biological Properties. Agronomy 9. American Society of Agronomy, Madison, USA.

Metson, A. J.; Gibson, E. Janice; Hunt, J. L.; Saunders, W. M. H. 1979. Seasonal variations in chemical composition of pasture. III. Silicon, aluminium, iron, zinc, copper and manganese. New Zealand Journal of Agricultural Research 22: 309-318.

Old, A.; Hedley, M.; Turner, M.; Heath, N.; Stuart, B. 2000. Influence of lime on pasture manganese concentrations and palatability In Soil Research: A knowledge industry for land based exporters (Eds L D Currie and P Loganathan). Occasional report No. 13. Fertiliser and Lime Research Centre, Massey
University, Palmerston North. pp 211-215.

Smith, G. S.; Edmeades, D. C. 1983. Manganese status of New Zealand pastures. 2. Pasture concentrations. New Zealand Journal of Agricultural Research 26: 223-225.

Smith, L. C.; Sinclair A. G. 1998. Effects and interactions of $\mathrm{P}$ fertiliser form and rates of lime on a clover/ryegrass sward. New Zealand Journal of Agricultural Research 41: 75-89.

Wheeler, D. M.; Edmeades, D. C.; Christie, R. A.; Gardner, R. C. 1992. Effect of aluminium on the growth of 34 plant species: a summary of results obtained in low ionic strength solution culture. Plant and Soil 146: 61-66

Wheeler, D. M. 1998. Investigation into the mechanisms causing lime responses in a grass/clover pasture on a clay loam soil. New Zealand Journal of Agricultural Research 41: 497-515.

Whitehead, D. C. 1973. Uptake and distribution of iodine in grass and clover plants grown in solution culture. Journal of Science Food and Agriculture 24: 43-50.

Williams, P. A.; Nes, P.; O'Connor, K. F. 1977. Macroelement pools and fluxes in tall-tussock (Chionochloa) grasslands, Canterbury, New Zealand. New Zealand Journal of Botany 15: 433 -476. 